Bernard Knight, 341 pages, Edinburgh, £9.95, Churchill Livingstone, 1987

Medical students traditionally enjoy lectures on forensic medicine but experience shows they retain very little of the content. This is a book on clinical forensic medicine, not on forensic pathology, and it is thoroughly interesting even when dealing with set pieces such as the coroner system and asphyxia.

It deals with the law and the court system in Scotland and Ireland in a separate chapter; others should emulate this simplification.

The first third of the book covers ethical and legal duties - indeed the first few chapters are devoted to ethics (consent highlighted by the Gillick case) and negligence.

There is extended coverage of the Warnock Report in excellent chapters on sterilisation and artificial insemination, organ transplantation and embryo research.

The forensic medicine content is sensibly problem-based and covers all the classical 'bloodthirsty' areas under situation headings, viz examination of motor vehicle injuries, sudden natural death, wounding (including firearm injuries). Police surgeons should heed the warnings about death in custody, and the confused area of intoxication and head injury. There are useful asides on solvent abuse, the sexual asphyxias and the distinction between sudden infant death and cot death. There is repeated emphasis throughout the text on express informed consent, but perhaps the attitude towards life insurance reports provided by private medical attendants is not critical enough. Most people who sign the company's blanket consent form have no idea of the material the doctor may be going to reveal.

The book was produced before the GMC/BMA tangle about blood-testing for HIV antibodies, indeed HIV and hepatitis B do not appear in the index. The advent of DNA fingerprinting is likely to revolutionise identification disputes, paternity-testing cases and the production of trace evidence in sexual offences.

Inevitably the chapter on the battered child will need radical revision, post Butler-Schloss. Tabulation where appropriate, is excellent and linedrawings helpful: the rabbinical androgynous picture on page 127 reminded me powerfully of the Turin shroud.

An excellent book targeted at senior students, junior doctors and general practitioners, inviting them to think about behaviour itself, not just behaviour calculated to avoid official censure.

D G CRAIG,

Senior Forensic Medical Examiner Metropolitan Police and Senior Lecturer, Department of General Practice, Guy's Hospital Medical School, London

\section{Healing and Suffering - The Christian Paradox}

Paul Feider, 96 pages, London, £2.95, Darton, Longman \& Todd, 1988

Fr Paul Feider's book is a most welcome addition to the debate on Christianity and suffering. Although this work appears in Great Britain after first being published in America eight years ago, the topic is an ever-present and seeming contradition; something which is agonised over daily.

The book is subtitled 'The Christian Paradox' and so it must seem to those Christians who regularly minister to the sick. 'Why does God allow this to happen?' is a question we can face daily. Paul Feider here does us all a service by taking us back to the setting of the historical Jesus and the roots of Christian healing. Yet whilst keen on history he is not afraid to promote biblical textual criticism in a most acceptable way. He points out that Jesus is the master psychologist and psychotherapist in that He saw the need to liberate, to set free those who came presenting a physical illness, which then as now, so often had a spiritual need at its root. Jesus saw that healing was needed at the deep level of cause. He did not just deal with the effect.

Fr Feider is similarly most positive when dealing with the personality of Jesus and in this too he displays an intelligent use of biblical texts. He goes on to range over the value of suffering even the value of a personal weakness in keeping us humble before God (one can easily think of St. Paul's 'thorn in the flesh'). The idea of 'faith relationship' is introduced and I find this a most valuable concept, dealing as it does with the expression of Christ's Love made manifest in the sufferer or in the minister or both, to bring about healing. The best place for this faith relationship, Fr Paul tells us, is in a healing community where love and peace create the atmosphere for healing.
I'm sure this is well understood and applied in the hospice situation, bu的 how many of us involved in busy majope National Health Service (NHS): hospitals would feel that we were in healing atmosphere? Would it were soOn this same point, the author speaks of the spiritual minister as being part of the 'healing team' - how constructive in would be if this too were so! Maybe this is a feature of healing institutions in America, but I wonder how many hospital chaplains really feel part of such a team, alongside their medica $\square$ colleagues?

There is much of importance in this easily read book especially so in the्ठ latter pages where Fr Feider tackles thequestion of non-healing. How often we have to explain carefully that 'being healed' is not always to be equated with 'getting better' as the world understands this. Even the encounter with Jesus, we are reminded, does not and never has resulted in the removal of all suffering, but promotes liberation freedom from a guilt-ridden past and thereby allows true healing to take् place.

At the end of the book is carro autobiographical testimony in whelpo the author speaks frankly of the healmg power of God's Love in his own Ifye을 This together with the chaptes summaries and the question and discussion points suggested make the book the ideal vehicle for a parish hospital or fellowship study course. M church bookstall will certainly be stocking this very worthwhile intelligent and reasonably priced volume.

\section{MICHAEL WHAWELL Vicar and Hospitaller, St Bartholomew's Hospital: London ECD}

\section{The Law Relating to the Health Care Professions}

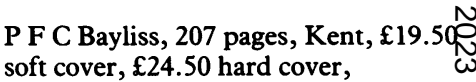

Ravenswood Publications, 1987

The myriad statutes and bills relating tô the health professions are understood? at least in general terms, by those in active practice of their chosen branch $\overline{-}$ Doctors are aware of the existence of theD Medical Act and its many up-dating 8 ? and also of the role and constitution ob the General Medical Council. Nurse who have the inclination, and the time 